\title{
OPEN Observational evidence of stratification control of upwelling and pelagic fishery in the eastern Arabian Sea
}

\begin{abstract}
Jayu Narvekar ${ }^{1 \bowtie}$, Riyanka Roy Chowdhury², Diksha Gaonkar ${ }^{1}$, P. K. Dinesh Kumar ${ }^{3}$ \& S. Prasanna Kumar ${ }^{1}$

Upwelling is a physical phenomenon that occurs globally along the eastern boundary of the ocean and supports pelagic fishery which is an important source of protein for the coastal population. Though upwelling and associated small pelagic fishery along the eastern Arabian Sea (EAS) is known to exist at least for the past six decades, our understanding of the factors controlling them are still elusive. Based on observation and data analysis we hypothesize that upwelling in the EAS during 2017 was modulated by freshwater-induced stratification. To validate this hypothesis, we examined 17 years of data from 2001 and show that inter-annual variability of freshwater influx indeed controls the upwelling in the EAS through stratification, a mechanism hitherto unexplored. The upper ocean stratification in turn is regulated by the fresh water influx through a combination of precipitation and river runoff. We further show that the oil sardine which is one of the dominant fish of the small pelagic fishery of the EAS varied inversely with stratification. Our study for the first time underscored the role of freshwater influx in regulating the coastal upwelling and upper ocean stratification controlling the regional pelagic fishery of the EAS.
\end{abstract}

Upwelling is a physical process that brings cold and nutrient-rich subsurface waters to the upper ocean. This process makes the nutrient-deficit and sunlight-replete waters of the upper ocean biologically productive by kick-starting the organic carbon production by phytoplankton through photosynthesis. Consequently, upwelling regions of the world ocean are also regions of intense fishery activities ${ }^{1}$. Though upwelling regions occupy only $5 \%$ of the total ocean area, it accounts for $25 \%$ of the global marine fish catch ${ }^{2}$. Usually, eastern boundaries of the ocean are well known for coastal upwelling ${ }^{3}$ and high chlorophyll $a$ (Chl-a) concentrations, such as California, Peru and Chile coasts in the Pacific and West Africa (Canary upwelling) and South-West Africa (Benguela upwelling) in the Atlantic. The exception is the coastal upwelling along Somalia ${ }^{4}$ and Arabia $^{5}$ in the Indian Ocean that occurs along the western boundary (Fig. 1). This is because the seasonal monsoon wind that blows in a south-westerly direction (summer or south-west monsoon) from June to September drives offshore Ekman transport supporting upwelling. The same south-west monsoon wind system also drives upwelling along the eastern Arabian Sea (EAS) ${ }^{6,7}$ (Fig. 1). This makes the Arabian Sea a unique basin with seasonal upwelling occurring along both eastern and western boundaries. Though the magnitude of upwelling in the EAS is much smaller compared to the other eastern boundary upwelling regions, it supports a substantial pelagic fishery like oil sardine, mackerel, and anchovies ${ }^{8-13}$ that supplements the nutrition requirement of the population in this region. In fact, the pelagic fishery from the EAS contributes to $20 \%$ of the total marine fish catch from India ${ }^{14}$, while the oil sardine alone accounts for $15 \%$ of the total marine fish landings of India ${ }^{15}$.

The regional oceanography of the EAS is unique ${ }^{16}$ with semi-annually reversing winds and coastal currents ${ }^{17}$, upwelling driven phytoplankton bloom and primary production ${ }^{6}$, seasonal hypoxia ${ }^{18}$, intrusion of high and low salinity waters ${ }^{19,20}$, presence of coastal Kelvin wave and westward propagating Rossby wave ${ }^{17}$, and occurrence of warm pool ${ }^{21}$. The coastal regions of the EAS receive substantial seasonal monsoon rainfall from June to September, which feeds the numerous small and medium rivers flowing through the coastal plain and joins

${ }^{1}$ CSIR-National Institute of Oceanography, Dona Paula, Goa 403004, India. ${ }^{2}$ Centre for Oceans, Rivers, Atmosphere and Land Sciences, Indian Institute of Technology Kharagpur, Kharagpur, West Bengal 721302, India. ${ }^{3}$ CSIR-National Institute of Oceanography Regional Centre, Dr. Salim Ali Road, Kochi 682018, India. ${ }^{\square}$ email: jnarvekar@nio.org 


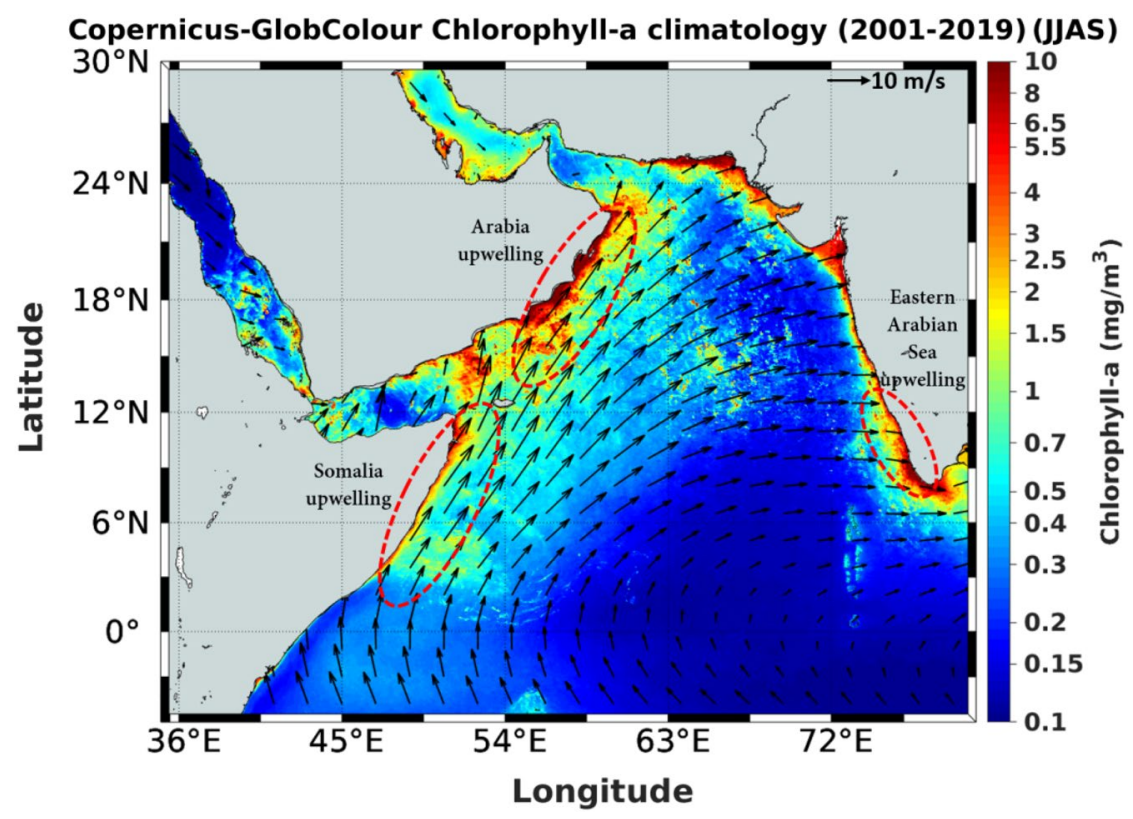

Figure 1. Map of the Arabian Sea showing the coastal upwelling regions off Somalia, Arabia and southern part of the EAS demarcated by red broken ellipse. Shading is the seasonal climatology (June-September) of chlorophyll $a$ (Chl-a) pigment concentration $\left(\mathrm{mg} / \mathrm{m}^{3}\right)$ derived from Copernicus-GlobColour merged product overlaid with climatological (June-September) wind vectors obtained from MERRA, both for 2001 to 2019. Figure was generated using MATALAB software. See text for details.

the Arabian Sea (Fig. 2, right panel). The prevailing coastal current, the West India Coastal Current (WICC), at this time of the year flows southward.

The upwelling along the EAS is a seasonal phenomenon, the report of which dates back to $1959^{6}$. There had been several studies aiming at understanding the process of upwelling based on water column data ${ }^{7,22-24}$. The above studies suggest that upwelling in the EAS starts towards the end of May with the reversal of wind from north-easterly direction to south-westerly direction, intensifies and persists during June to August, starts diminishing by September, and ceases completely by October when the south-westerly wind collapses. Spatially, upwelling is most intense and active in the southern part of EAS along the littoral state of Kerala (Fig. 2), appearing first in the southernmost latitude off Kanyakumari $\left(8^{\circ} \mathrm{N}\right)$ towards the end of May, slowly progresses northward with the advancement of south-west monsoon winds and extends up to the coast of Ratnagiri $\left(17^{\circ} \mathrm{N}\right)$ by August ${ }^{22,25,26,30}$. Previous studies suggest that upwelling in the EAS is driven by a combination of local forcing through wind ${ }^{7,27,28}$ and remote forcing via coastal Kelvin wave ${ }^{17,22,29-32}$. In spite of the above mentioned studies our understanding of upwelling along the EAS is incomplete. Even lesser is our knowledge on its inter-annual variability with only two studies ${ }^{33,34}$ both of which speculated wind as the most probable cause. Though there had been some attempts to unravel the relationship between upwelling and small pelagic fishery of the EAS ${ }^{13,14,26,35}$, the role of regional ocean processes on fishery still remains elusive.

The above motivated the present study and prompted us to ask the following question: What is the role of atmospheric drivers and ensuing ocean processes in regulating the upwelling and regional small pelagic fishery of the EAS? We seek answer to the above question by examining (1) whether there are any forcing other than wind and coastal Kelvin wave that could bring about changes in the process of upwelling, and (2) if so, can such forcing explain the observed inter-annual variability in upwelling and its connection to small pelagic fishery of the EAS. Using a combination of in situ as well as remote sensing data we show that the upper ocean stratification induced by freshwater input is an important forcing that modulates upwelling in the EAS in 2017. It is further shown that the upwelling at inter-annual time scale is regulated by the variability in rainfall, river discharge and oceanic precipitation, a result which is so far unexplored. Finally, we show a mechanistic relationship between oil sardine, a small pelagic fish that dominates the EAS upwelling region, and water column stratification at inter-annual time scale.

\section{Results and discussion}

The water column temperature, salinity, and static stability from 8 to $21^{\circ} \mathrm{N}$ along the EAS were examined to understand the vertical structure and latitudinal extent of upwelling during August 2017. Thereafter, the latitudinal variability of the depth of $24^{\circ} \mathrm{C}$ isotherm $\left(\mathrm{D}_{24}\right.$, a proxy for upwelling), upper water column $(0-1 \mathrm{~m})$ static stability (an indicator of stratification) and wind forcing via Ekman vertical velocity and Ekman mass transport (EMT) were analysed to infer about the forcing that controls upwelling process. Subsequently, the rainfall and cumulative discharge from 21 major rivers and oceanic precipitation in the southern part of the EAS during 


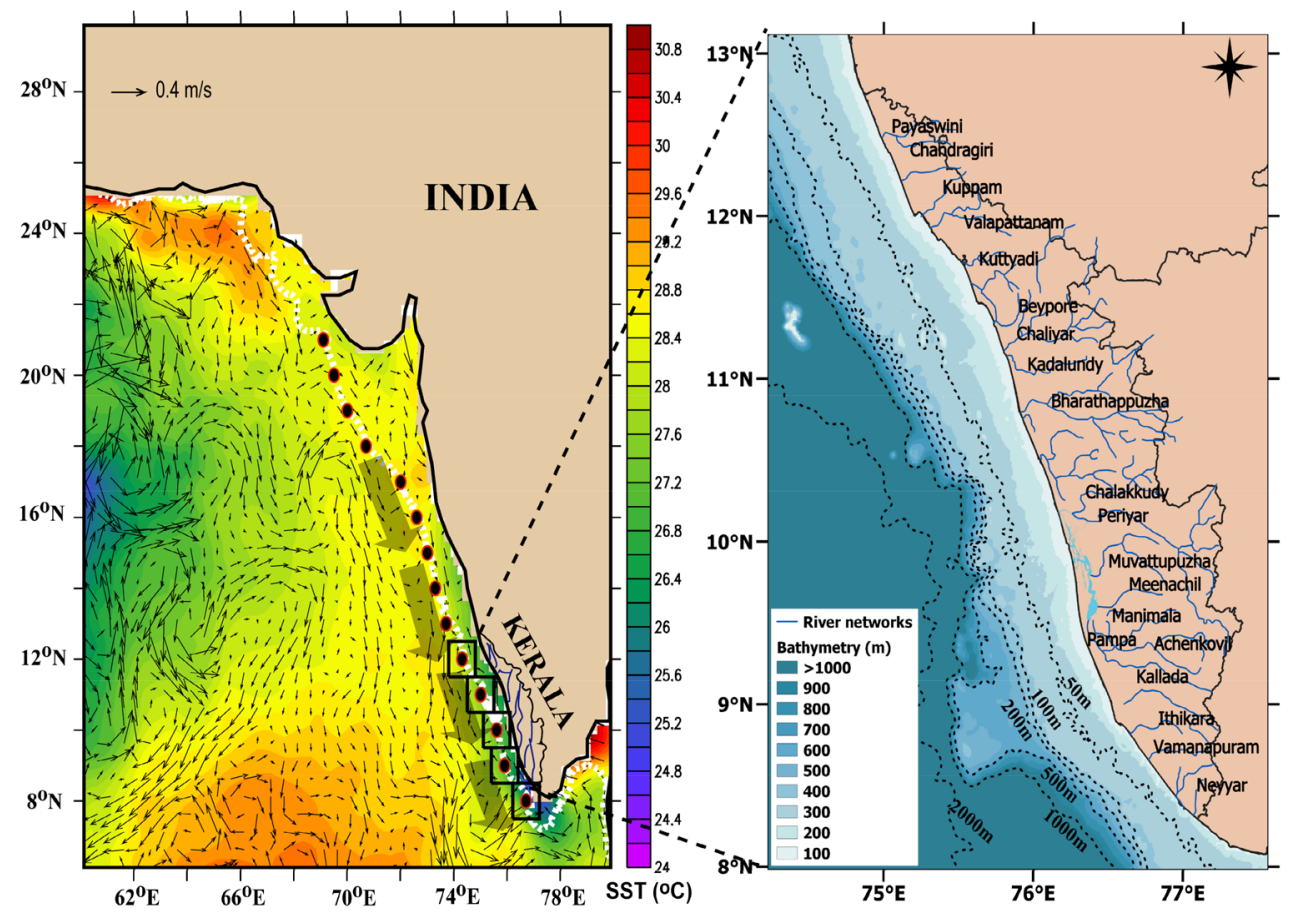

Figure 2. Location map of the eastern Arabian Sea showing the study area (left panel). Red circles filled with black are the station locations from where in situ water column data were collected during 3rd to 28th August 2017. The white dashed line represents the $200 \mathrm{~m}$ depth contour. Shading is the sea surface temperature (SST, ${ }^{\circ} \mathrm{C}$ ) and overlaid vectors represent the geostrophic current both for August 2017 obtained from NOAA and CMEMS respectively. The black squares are the boxes centered at in situ stations from $8^{\circ}$ to $12^{\circ} \mathrm{N}$ used for the calculation of time series of various parameters. The wide grey-shaded arrows along the EAS represent the West India Coastal Current (WICC). The river network map of Kerala along with bathymetry is also given (right Panel). Figure was created using using Ferret and QGIS software. See text for details.

2001 to 2019 were analysed along with inter-annual variability of $\mathrm{D}_{24}$ and oil sardine data to understand the role of stratification in controlling the oil sardine fishery.

Vertical structure of water column parameters. The salient feature of the vertical thermal structure was the gradual tendency of up-sloping of isotherms from 8 to $10^{\circ} \mathrm{N}$, and a sharp up-sloping of isotherms up to $11^{\circ} \mathrm{N}$, followed by an equally sharp down-sloping of isotherms up to $13^{\circ} \mathrm{N}$ (Fig. 3a). For example, the $24^{\circ} \mathrm{C}$ isotherm (white broken line in Fig. 3a) which was at $35 \mathrm{~m}$ at $8^{\circ} \mathrm{N}$ shoaled to $10 \mathrm{~m}$ at $11^{\circ} \mathrm{N}$ and then deepened to $65 \mathrm{~m}$ at $13^{\circ} \mathrm{N}$. A thick isothermal layer of almost uniform thickness of $40 \mathrm{~m}$ was noticed north of $13^{\circ} \mathrm{N}$, where the temperature ranged from $28.5^{\circ}$ to $28{ }^{\circ} \mathrm{C}$. However, the $26.5^{\circ} \mathrm{C}$ (black broken line in Fig. 3a) and $27^{\circ} \mathrm{C}$ isotherms broke into the surface in the region between $10^{\circ}$ and $11^{\circ} \mathrm{N}$, indicating the signature of active upwelling. In general, the temperature of the upper $10 \mathrm{~m}$ water column south of $11^{\circ} \mathrm{N}$ was colder than $27^{\circ} \mathrm{C}$, while that in the north was warmer than $28^{\circ} \mathrm{C}$. Thus, from the vertical temperature distribution, we infer that the upwelling was active only in the vicinity of $11^{\circ} \mathrm{N}$, where the surfacing of isotherms with colder waters was noticed. In fact, the depth of the $24^{\circ} \mathrm{C}$ isotherm could serve as an indicator of upwelling. Based on earlier studies ${ }^{22,26}$ we expected the upwelling to be most active in the EAS from $8^{\circ}$ to $13^{\circ} \mathrm{N}$. However, in the present study active upwelling was noticed only at $11^{\circ} \mathrm{N}$, while in the region north and south of it indicated suppression of upwelling. Based on the latitudinal extent of the shallow $\mathrm{D}_{24}$, we infer that the tendency of upwelling extended up to $13^{\circ} \mathrm{N}$. In order to further understand why active upwelling was confined in the vicinity of $11^{\circ} \mathrm{N}$ in August 2017, the vertical salinity distribution was examined.

The vertical salinity structure showed the presence of low salinity waters in the upper water column between $8^{\circ}$ and $13.5^{\circ} \mathrm{N}$ (Fig. $3 \mathrm{~b}$ ) with the lowest salinity of 34.1 occurring at $9^{\circ} \mathrm{N}$. North of $13^{\circ} \mathrm{N}$ the salinity showed a gradual increase with latitude. Note the thick layer of high salinity (36.7) in the upper $50 \mathrm{~m}$ between $19^{\circ}$ and $21^{\circ} \mathrm{N}$ and the subsurface salinity maxima (36.3) between $13^{\circ}$ and $15^{\circ} \mathrm{N}$, which are the signature of the Arabian Sea high salinity water mass ${ }^{19}$. In the south, the thickness of the layer of low salinity water decreased from $8^{\circ}$ to $13^{\circ} \mathrm{N}$. For example, the 35.5 isohaline (the upper white broken line in Fig. 3b), which is taken as the boundary of low salinity water, was $20 \mathrm{~m}$ deep at $8^{\circ} \mathrm{N}$. It shoaled to $10 \mathrm{~m}$ at $11^{\circ} \mathrm{N}$ and deepened once again, finally surfaced between $13^{\circ}$ and $14^{\circ} \mathrm{N}$ indicating the northernmost limit of the low salinity water. Similar low salinity values of 34.2 and 34.8 were reported off Cochin $\left(9.9^{\circ} \mathrm{N}\right)$ and Kanyakumari $\left(8^{\circ} \mathrm{N}\right)$ respectively in August based on measurements ${ }^{36}$. In the present case, the observed pattern of distribution of low salinity water (Fig. 3b) was consistent with temperature (Fig. 3a). Recall the surfacing of isotherms between $10^{\circ}$ and $11^{\circ} \mathrm{N}$ indicating the upwelling, which also should bring subsurface high salinity waters to the surface. An indication of this is 

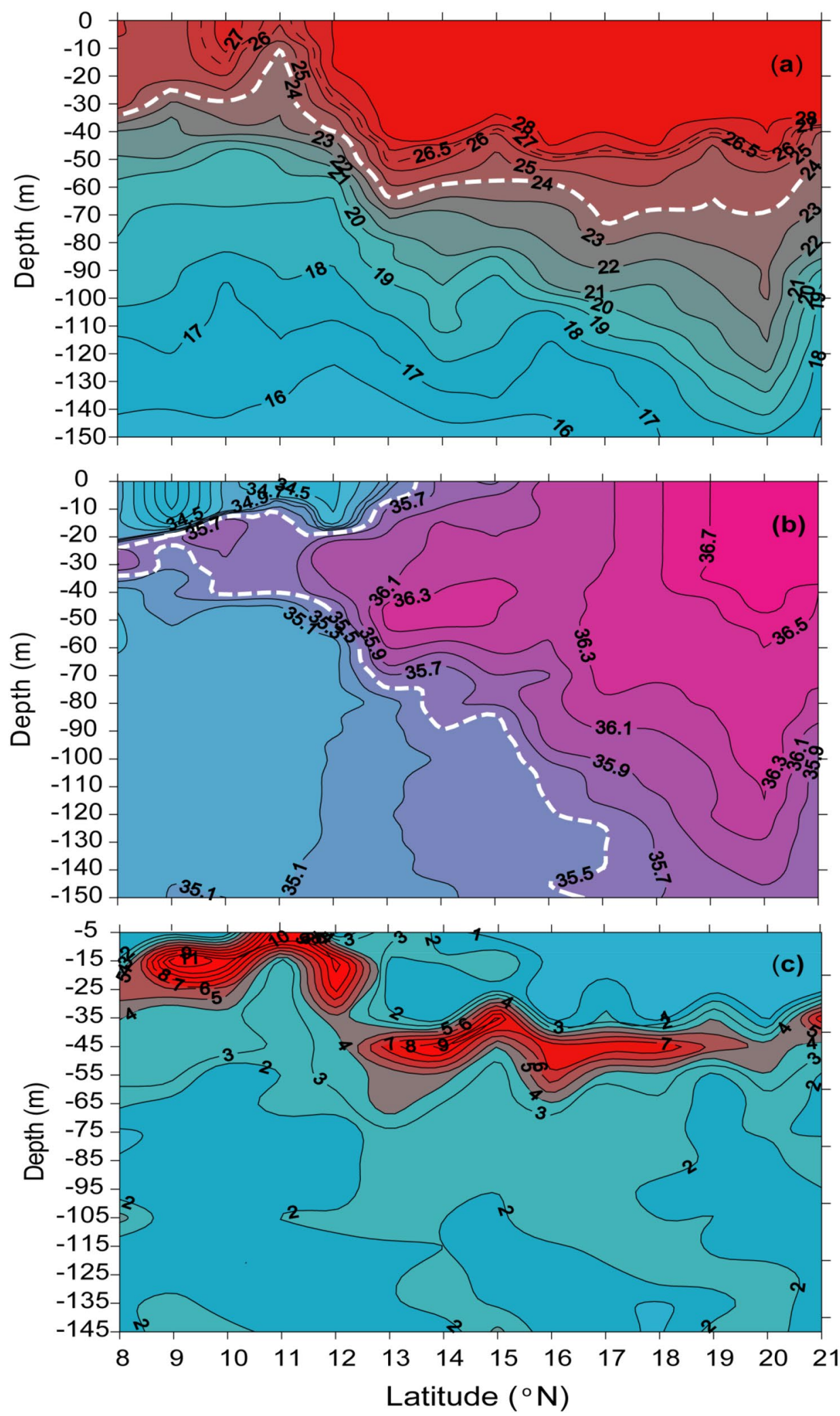

Figure 3. Vertical distribution of $(\mathbf{a})$ temperature $\left({ }^{\circ} \mathrm{C}\right),(\mathbf{b})$ salinity and (c) static stability $\left(\mathrm{E}, \mathrm{m}^{-1}\right)$ from $8^{\circ}$ to $21^{\circ}$ $\mathrm{N}$ along the eastern Arabian Sea during August 2017. The white broken line in (a) is the $24^{\circ} \mathrm{C}$ isotherm, while that in (b) is the 35 isohaline. 


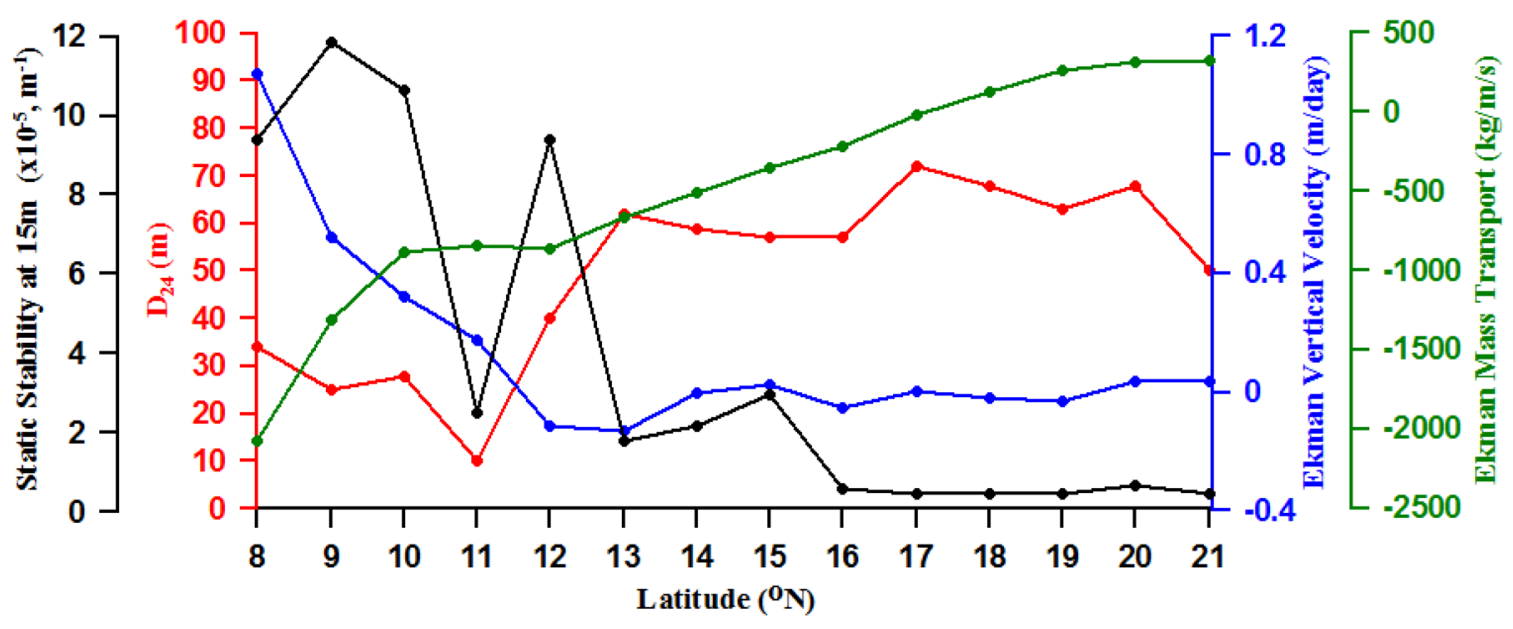

Figure 4. Latitudinal variation of Ekman mass transport (EMT) $(\mathrm{kg} / \mathrm{m} / \mathrm{s}$, green solid line), Ekman vertical velocity ( $\mathrm{m} /$ day, blue solid line), static stability in the upper $15 \mathrm{~m}$ of the water column $\left(\mathrm{m}^{-1}\right.$, black solid line), and depth of $24^{\circ} \mathrm{C}$ isotherm $\left(\mathrm{D}_{24}\right)\left(\mathrm{m}\right.$, red solid line) from $8^{\circ}$ to $21^{\circ} \mathrm{N}$ along the eastern Arabian Sea during August 2017.

discernible in the salinity distribution where surfacing of 34.7 isohalines were seen between $10^{\circ}$ and $11^{\circ} \mathrm{N}$. The presence of low salinity water in the upper water column could potentially impart strong stratification. Hence, to ascertain this aspect we analysed the static stability of the water column which is a measure of stratification.

The vertical distribution of static stability $\left(\mathrm{E}, \mathrm{m}^{-1}\right)$ showed high values with strong gradient confined within upper $30 \mathrm{~m}$ between $8^{\circ}$ and $13^{\circ} \mathrm{N}$, and below this depth the values decreased rapidly (Fig. $3 \mathrm{c}$ ). North of $13^{\circ} \mathrm{N}$, a region of strong gradient in static stability was located between 30 and $60 \mathrm{~m}$, while below this depth values decreased. The first region with high static stability located in the upper $30 \mathrm{~m}$ of the water column in the south between $8^{\circ}$ and $13^{\circ} \mathrm{N}$ coincided with the region of low salinity waters. This clearly indicated the role of freshwater in controlling the stability of the upper water column and is the signature of haline stratification. The second region with high static stability located in the sub-surface layer of the water column north of $13^{\circ} \mathrm{N}$ coincided with the upper thermocline. This is the manifestation of thermal stratification. Note that at $11^{\circ} \mathrm{N}$ the static stability was the least with nearly the same value in the upper $10 \mathrm{~m}$ and the isolines of the static stability outcropped into the surface. It is appropriate to mention here that though it is the freshwater influx that dominantly controls the stratification in the upper water column in the southern part of the EAS, the temperature of the upper thermocline also contributed to the overall stratification.

Latitudinal variability of wind-driven Ekman dynamics. In spite of the presence of fresh waterdriven stratification between $8^{\circ}$ and $13^{\circ} \mathrm{N}$, the upwelling was active at $11^{\circ} \mathrm{N}$. Since the coastal wind is one of the factors that is known to modulate the upwelling in the $\mathrm{EAS}^{7,22}$, the latitudinal variation of wind-driven Ekman mass transport (EMT), Ekman vertical velocity, static stability in the upper $15 \mathrm{~m}$ of the water column, and $\mathrm{D}_{24}$ at stations from $8^{\circ}$ to $21^{\circ} \mathrm{N}$ (Fig. 4) were examined. We used $\mathrm{D}_{24}$ instead of the commonly used $\mathrm{D}_{26}$ as an indicator of upwelling, though both lie in the upper thermocline, due to the following reason. During upwelling the 26 degree isotherm in the southern part of EAS often outcrops and hence has the potential of being influenced by the local air-sea fluxes. EMT showed the highest negative value of $2000 \mathrm{~kg} / \mathrm{m} / \mathrm{s}$ at $8^{\circ} \mathrm{N}$ and represents an offshore transport (negative) of water favouring upwelling. The EMT rapidly reduced to less than half its value at $10^{\circ} \mathrm{N}$ and remained almost uniform up to $12^{\circ} \mathrm{N}$. Beyond this latitude the EMT decreased rapidly becoming zero at $17^{\circ}$ $\mathrm{N}$, which indicated the northward limit of potential upwelling. Between 18 and $21^{\circ} \mathrm{N}$ the EMT was small but onshore (positive) indicating condition favourable for sinking. Commensurate with EMT, the Ekman vertical velocity was highest $\left(1.1 \mathrm{~m} /\right.$ day) and positive (Ekman suction) at $8^{\circ} \mathrm{N}$. Beyond this latitude, the Ekman vertical velocity though decreased rapidly, remained positive up to $11^{\circ} \mathrm{N}(0.2 \mathrm{~m} /$ day $)$, which indicated the conditions favourable for upwelling. However, from $12^{\circ}$ to $21^{\circ} \mathrm{N}$ the values were close to zero or small and negative (Ekman pumping) indicating neutral condition or condition suitable for sinking. In spite of substantial positive Ekman vertical velocity and large offshore EMT from 8 to $11^{\circ} \mathrm{N}$, the thermal structure did not show the signature of active upwelling in this region, except at $11^{\circ} \mathrm{N}$ (Fig. 2a). The $\mathrm{D}_{24}$, though showed a weak shoaling tendency from $8^{\circ}$ to $10^{\circ} \mathrm{N}$ was deeper than $25 \mathrm{~m}$. The static stability in the upper $15 \mathrm{~m}$ of the water column at these latitudes was high with values ranging from 10 to $12 \times 10^{-5} \mathrm{~m}^{-1}$ indicating strong stratification. However, at $11^{\circ} \mathrm{N}$ the $\mathrm{D}_{24}$ was the shallowest $(10 \mathrm{~m})$ and the static stability showed a rapid decrease to $2 \times 10^{-5} \mathrm{~m}^{-1}$. This point to the fact that the strong upwelling observed at $11^{\circ} \mathrm{N}$ was driven by the reduction of the stratification of the water column. Recall that the thickness of low salinity water was the least at $11^{\circ} \mathrm{N}$ (Fig. 3b) and this led to the decrease in static stability and stratification of the upper water column. North of $11^{\circ} \mathrm{N}$ the $\mathrm{D}_{24}$ deepened sharply to $60 \mathrm{~m}$ at $13^{\circ} \mathrm{N}$ and remained uniform until $21^{\circ} \mathrm{N}$. Both $\mathrm{D}_{24}$ and static stability showed that the northern limit of the upwelling tendency was $13^{\circ} \mathrm{N}$. Hence, our inference is that the prevailing winds were able to create a condition favourable for upwelling from $8^{\circ}$ to $12^{\circ} \mathrm{N}$ through potential offshore EMT and subsequent Ekman suction. However, the presence of low salinity water in the upper $20 \mathrm{~m}$ of the water column increased the static stability and stratification. This inhibited the process of upwelling except at $11^{\circ} \mathrm{N}$ where the thickness of the low salinity layer was 


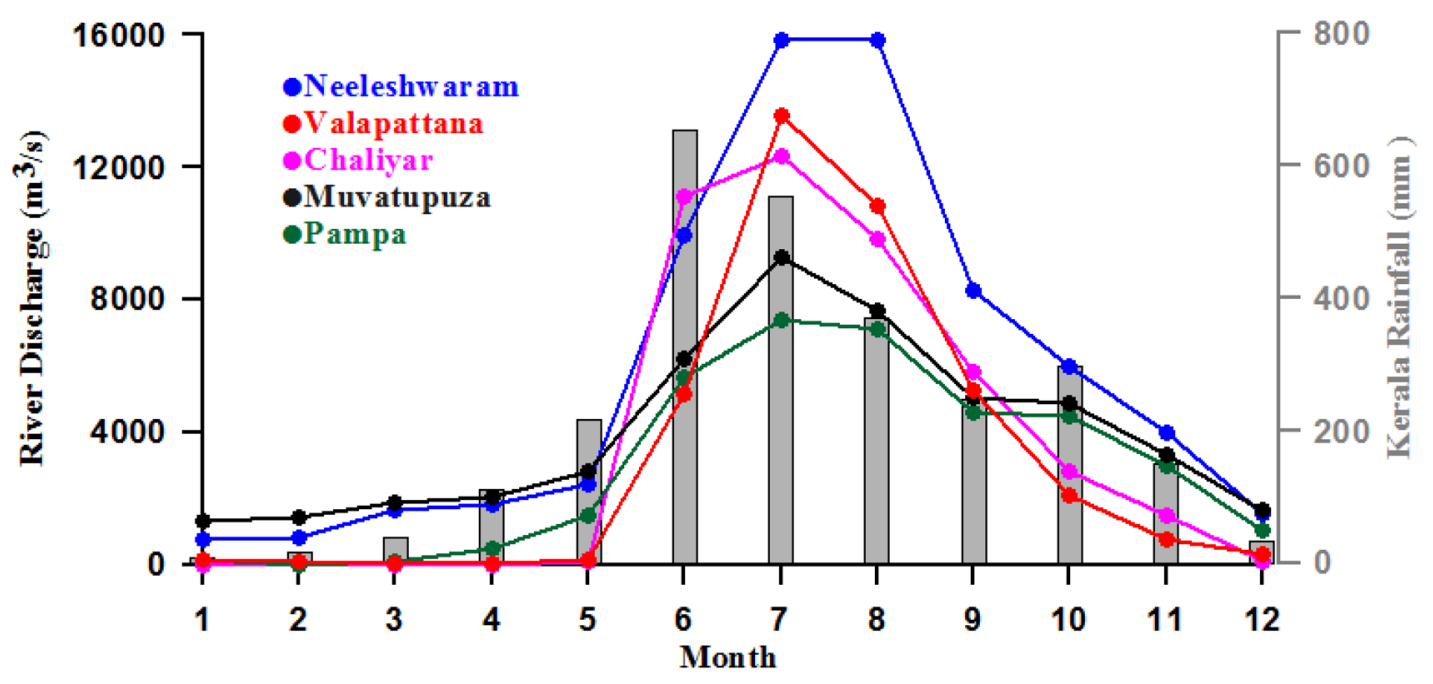

Figure 5. Monthly mean climatology of rainfall (2001-2019) (mm, grey bar) and river discharge (2001-2018) $\left(\mathrm{m}^{3} / \mathrm{s}\right)$ from 5 major rivers (solid lines) of the littoral state of Kerala, India.

\begin{tabular}{|l|l|l|l|l|l|}
\hline Predictor & Rank & Regression coefficient & Standard error & $\boldsymbol{t}$ & $\boldsymbol{p}>|\boldsymbol{t}|$ \\
\hline Oceanic precipitation & 1 & 0.682 & 0.183 & 3.733 & $0.002^{\star}$ \\
\hline River discharge & 2 & 0.663 & 0.187 & 3.547 & $0.003^{\star}$ \\
\hline Kerala rainfall & 3 & 0.626 & 0.195 & 3.214 & $0.005^{*}$ \\
\hline
\end{tabular}

Table 1. Multiple linear regression analysis with de-trended $D_{24}$ as the predictand and parameters such as oceanic precipitation, river discharge, and Kerala rainfall as predictors for the period 2001-2019. ${ }^{\star}$ Denotes the values that are statistically significant at $p<0.05$.

the least. Though wind-forcing was favourable for upwelling in the region from $8^{\circ}$ to $11^{\circ} \mathrm{N}$, the freshwater flux driven upper ocean stratification counteracted it. However, at $11^{\circ} \mathrm{N}$ the wind-forcing was able to overwhelm the stratification. It is important to note that upwelling has considerable spatial variability within the EAS due to the variability in wind as well as the freshwater influx, both of which are strongly related to the south-west monsoon.

It is amply clear from the above that the presence of low salinity water in the upper water column in the southern part of the EAS played an important role in modulating upwelling in August 2017 through stratification (static stability). The source of freshwater could either be river runoff or oceanic precipitation or both. In the next section, we examine the role of both river runoff and oceanic precipitation in controlling the upwelling.

Rainfall, river discharge and upwelling. The littoral state of Kerala $\left(8^{\circ} 18^{\prime} \mathrm{N}\right.$ and $12^{\circ} 48^{\prime} \mathrm{N}$ latitude and $74^{\circ} 52^{\prime} \mathrm{E}$ and $77^{\circ} 2^{\prime} \mathrm{E}$ longitude; See Fig. 2, right panel) adjoining the southern part of the EAS has 41 westflowing small rivers that join the Arabian Sea. These rivers are rain-fed with an annual average rainfall of 3000 $\mathrm{mm}^{37}$. To understand the seasonal cycle of river discharge in the context of the seasonal rainfall, the monthly mean climatology (2001-2018) of five major rivers and rainfall of Kerala (2001-2019) are presented in Fig. 5. The Kerala rainfall showed an annual cycle with rainfall increasing from January, attaining the highest value in June $(650 \mathrm{~mm})$ and then declining rapidly to December. The months from June to October, representing the south-west monsoon period, accounts for the bulk of the annual rainfall. The discharge from the five major rivers also showed a similar annual cycle commensurate with that of rainfall with most of the discharges during the south-west monsoon months. Note that the peak discharge was in July, a month after the peak in rainfall. Thus, it is evident that the rainfall driven river discharge which peaks during south-west monsoon could contribute to the freshening of surface water off the littoral state of Kerala between $8^{\circ}$ and $12^{\circ} \mathrm{N}$ thereby increasing the stratification of the water column and impacting the upwelling. Further confirmation of the role of rain fall, river discharge, and stratification using multiple linear regression analysis is presented in Table 1 and discussed in subsequent paragraph.

To ascertain the role of freshwater input in controlling the upwelling through increased stratification on interannual time scale, the discharge of 21 major rivers and rainfall in the littoral state of Kerala along with oceanic precipitation and $\mathrm{D}_{24}$ were examined. The river discharge and Kerala rainfall were cumulated for each year from June to September, while the oceanic precipitation and $\mathrm{D}_{24}$ were averaged from June to September and also over the boxes from $8^{\circ}$ to $12^{\circ} \mathrm{N}$, and presented for the period from 2001 to 2019 (Fig. 6). Since the time variation of $\mathrm{D}_{24}$ showed a trend, the de-trended $\mathrm{D}_{24}$ was also presented in Fig. 6 . Note that the boxes from $8^{\circ}$ to $12^{\circ} \mathrm{N}$ lie in the core upwelling region in the southern part of the EAS. 


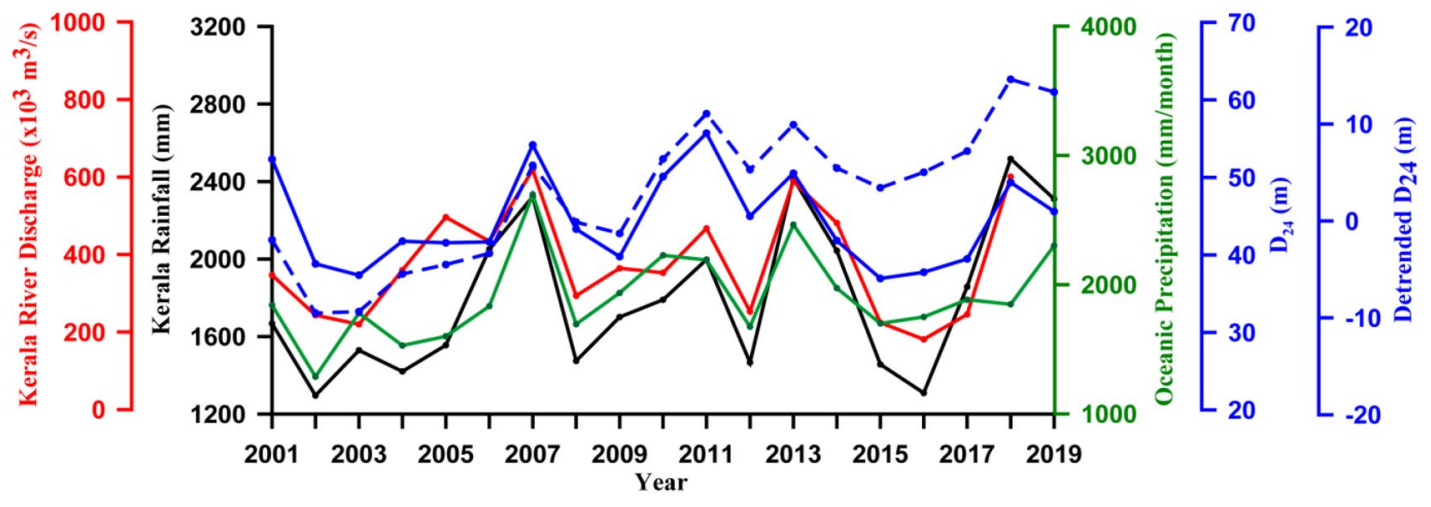

Figure 6. Time series of rainfall ( $\mathrm{mm}$, black solid line) and river discharge $\left(\times 10^{3} \mathrm{~m}^{3} / \mathrm{s}\right.$, red solid line) from Kerala, oceanic precipitation ( $\mathrm{mm} / \mathrm{month}$, green solid line), depth of $24^{\circ} \mathrm{C}$ isotherm $\left(\mathrm{D}_{24}\right)$ ( $\mathrm{m}$, blue broken line), and de-trended depth of $24^{\circ} \mathrm{C}$ isotherm (m, blue solid line) from 2001 to 2019, except for river discharge which is up to 2018. The river discharge and rainfall from Kerala were cumulated for June to September, while the oceanic precipitation and $\mathrm{D}_{24}$ were averaged for June to September and also over the boxes from $8^{\circ}$ to $12^{\circ} \mathrm{N}$. See Fig. 2 for location of boxes.

The salient feature of the time series (Fig. 6) was the co-variation of Kerala rainfall, river discharge and the oceanic precipitation (referred as freshwater influx) with $\mathrm{D}_{24}$. The $\mathrm{D}_{24}$ / de-trended $\mathrm{D}_{24}$ showed a strong relationship with freshwater influx. For example, during 2001, 2007, 2011, 2013, and 2018 when freshwater influx showed high values, both $\mathrm{D}_{24}$ and de-trended $\mathrm{D}_{24}$ also showed high values (Fig. 6). The deepening of $\mathrm{D}_{24} /$ de-trended $\mathrm{D}_{24}$ implied weakening of upwelling. In a similar way, when freshwater influx was low during 2002, 2008, 2012 and 2016 , the $\mathrm{D}_{24}$ also was low. Shoaling of $\mathrm{D}_{24}$ implied strengthening of upwelling. Both cases cited above implied a strong inverse association of upwelling with freshwater influx on inter-annual time scale. A similar inverse relation of upwelling and rainfall was reported from Benguela upwelling region ${ }^{38}$. In another study the changes in the coastal sea level in the Gulf of Alaska was found to be related more strongly to precipitation and runoff rather than changes in wind stress ${ }^{39}$.

To further elucidate the relationship between upwelling and freshwater influx, a multiple linear regression analysis ${ }^{26}$ was performed to assess the relationship between three predictors and a predictand. The de-trended $\mathrm{D}_{24}$ was taken as the predictand and three parameters such as oceanic precipitation, river discharge, and Kerala rainfall were taken as predictors for the period 2001 to 2019. The predictors were ranked on the basis of the magnitude of their regression coefficient presented in Table 1. Oceanic precipitation was the most important predictor (ranked 1), followed by river discharge, and then Kerala rainfall (ranked 3). All the three predictors were significant at $95 \%$. Note that there was not much difference among the 3 predictors indicating that on interannual time scale oceanic precipitation, river discharge and Kerala rainfall were almost equally and positively correlated with $\mathrm{D}_{24}$.

Thus, based on the above we infer that the increased freshwater influx in the southern part of the EAS due to a combination of rainfall and subsequent river runoff along with the oceanic precipitation lead to an increase in the static stability of the upper water column along the coastal and shelf regions. This in turn increased the upper ocean stratification which led to the reduction of upwelling. In a wind-driven upwelling system, the EMT is often taken as an indicator of upwelling intensity ${ }^{22,33}$. To examine the role of stratification as well as wind during August 2017, the correlation of $\mathrm{D}_{24}$ with EMT and static stability were computed by taking values at stations from $8^{\circ}$ to $21^{\circ} \mathrm{N}$ (Fig. 7). The static stability showed an inverse correlation with $\mathrm{D}_{24}$, while the EMT showed a direct correlation. However, the correlation was stronger with $\mathrm{D}_{24}(\mathrm{r}=-0.93)$ than with EMT $(\mathrm{r}=0.69)$ and both were significant at $99 \%$ confidence level ( $p$ values 0.0001 and 0.005 respectively). The results implied that both wind and stratification are important in regulating upwelling.

In the EAS, the upwelling intensity showed a considerable spatial variation as was the case during 2017 . This spatial variation is driven by a combination of forcing such as wind and stratification, both of which showed considerable variability with latitude. The wind associated with the south-west monsoon has large spatial variability, and so also the rainfall. Recall that during August 2017 upwelling along the EAS was prominent at $11^{\circ}$ $\mathrm{N}$, which was a manifestation of the interplay between wind and stratification. The present study also showed that the rainfall, river discharge and stratification have considerable inter-annual variability. Hence, the spatial variation of the intensity of upwelling in the EAS would strongly depend on the relative dominance among the wind and the stratification.

Role of stratification in regulating chlorophyll and small pelagic fishery. Having examined the role of stratification in the process of upwelling in the EAS, we now focus on its impact on phytoplankton and fishery of this region. The oil sardines being dominant fish among the small pelagic fishery in the EAS ${ }^{13,15}$ we used the oil sardine landings data for our analysis. As the oil sardine landings from Kerala contribute nearly to $85 \%$ of the national oil sardine landings ${ }^{40}$, the national landings data would serve as a proxy for Kerala. Hence, the data on annual oil sardine landings (tonnes) available from 2004 to 2018 along with static stability $\left(\mathrm{m}^{-1}\right)$, de-trended $\mathrm{D}_{24}$, and Chl-a $\left(\mathrm{mg} / \mathrm{m}^{3}\right)$ were examined (Fig. 8). The static stability, $\mathrm{D}_{24}$, and Chl-a were averaged from $8^{\circ}$ to $12^{\circ} \mathrm{N}$ and for the months June to September. The sardine landing data and static stability showed an 

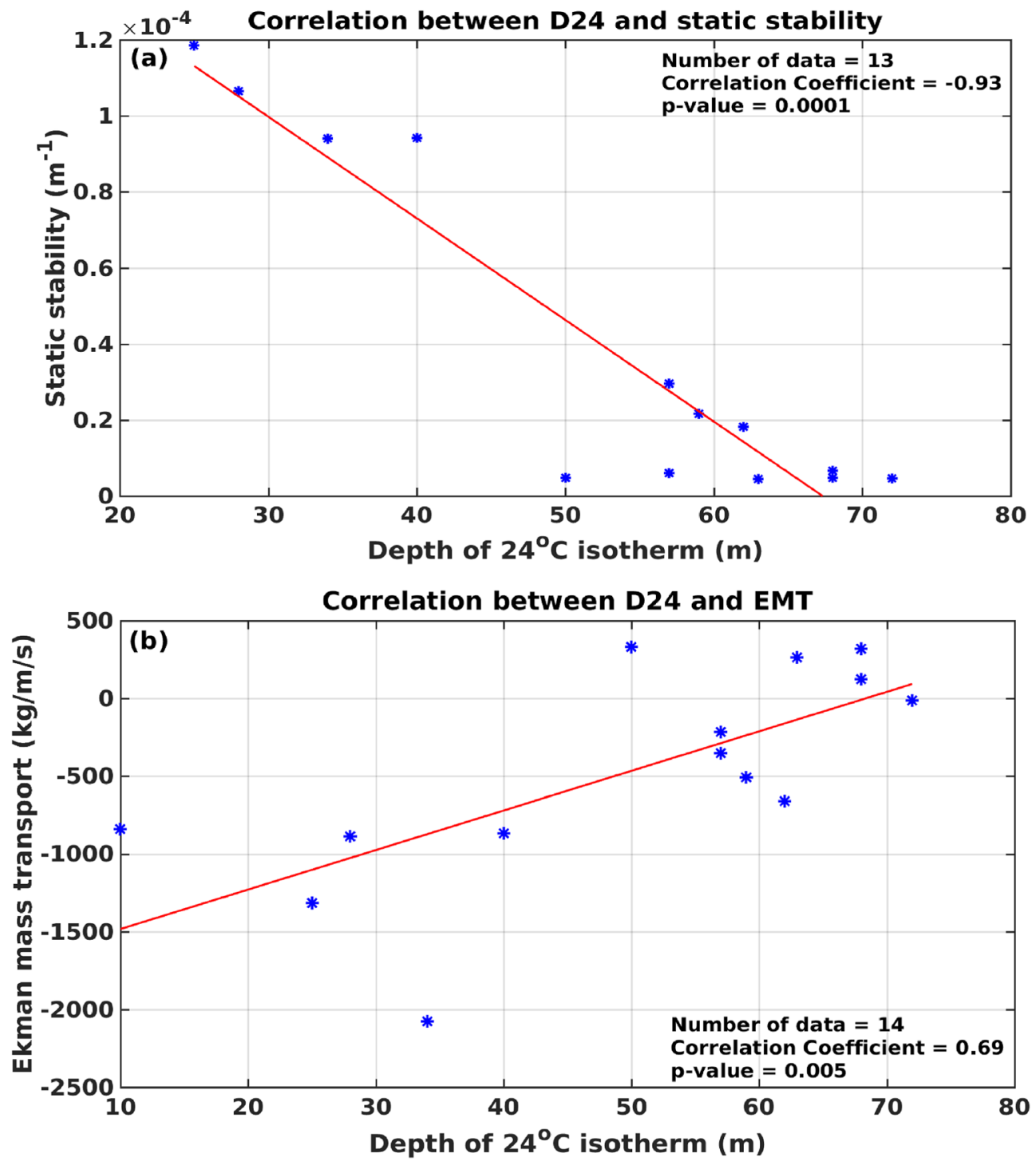

Figure 7. Correlation of depth of $24^{\circ} \mathrm{C}$ isotherm $\left(\mathrm{D}_{24}, \mathrm{~m}\right)$ with $(\mathbf{a})$ static stability $\left(\mathrm{m}^{-1}\right)$ in the upper $15 \mathrm{~m}$ of the water column, and (b) Ekman mass transport $\left(\right.$ EMT) $(\mathrm{kg} / \mathrm{m} / \mathrm{s})$. All parameters were taken at 14 stations from $8^{\circ}$ to $21^{\circ} \mathrm{N}$.

inverse variation. For example, in the years 2005, 2009, 2015, and 2018 when the oil sardine landings were low, the static stability showed high values. Similarly, in the years 2007, 2012, and 2017 when the oil sardine landings were high, the static stability showed low values except in 2017 . However, when the oil sardine landing crashed in 2015 we did not see a corresponding increase in static stability, but noticed a marginal decline. This is an anomaly which would need an explanation. An examination of ENSO (El Nino-Southern Oscillation) (https://origin.cpc. ncep.noaa.gov/products/analysis_monitoring/ensostuff/ONI_v5.php) and IOD (Indian Ocean Dipole) (http:// www.bom.gov.au/climate/iod/) indices showed a co-occurrence of both in 2015. In fact, the year experienced one of the strongest El Nino (ENSO index 2.9) of the last two decades and a moderate positive IOD (index 0.7). During this combined event, the western Arabian Sea becomes warmer than normal and impacts upwelling. We speculate that the steep fall in oil sardine landing in 2015 was the manifestation of the co-occurrence of positive ENSO and IOD events.

A comparison of oil sardine landings with de-trended $\mathrm{D}_{24}$, however, showed a co-variation, except in 2012, 2013 and 2018, which is at variance with our expectation. The reason for the observed inverse variation of static stability and oil sardine landings lies in the fact that when the static stability of the water column is high, like that in 2017, upwelling is reduced due to strong stratification. This will restrict the nutrient input from subsurface to the upper ocean thereby reducing the chlorophyll biomass, which is a proxy for the phytoplankton biomass. Oil sardine being planktivorous fish ${ }^{41}$ a reduction in the phytoplankton biomass due to increased static stability (stratification) will reduce the biomass of oil sardine as well.

Hence, in an upwelling region like the EAS an inverse variation of Chl-a with static stability was expected. However, the results showed that the Chl-a co-varied with static stability (Fig. 8). For example, when static 


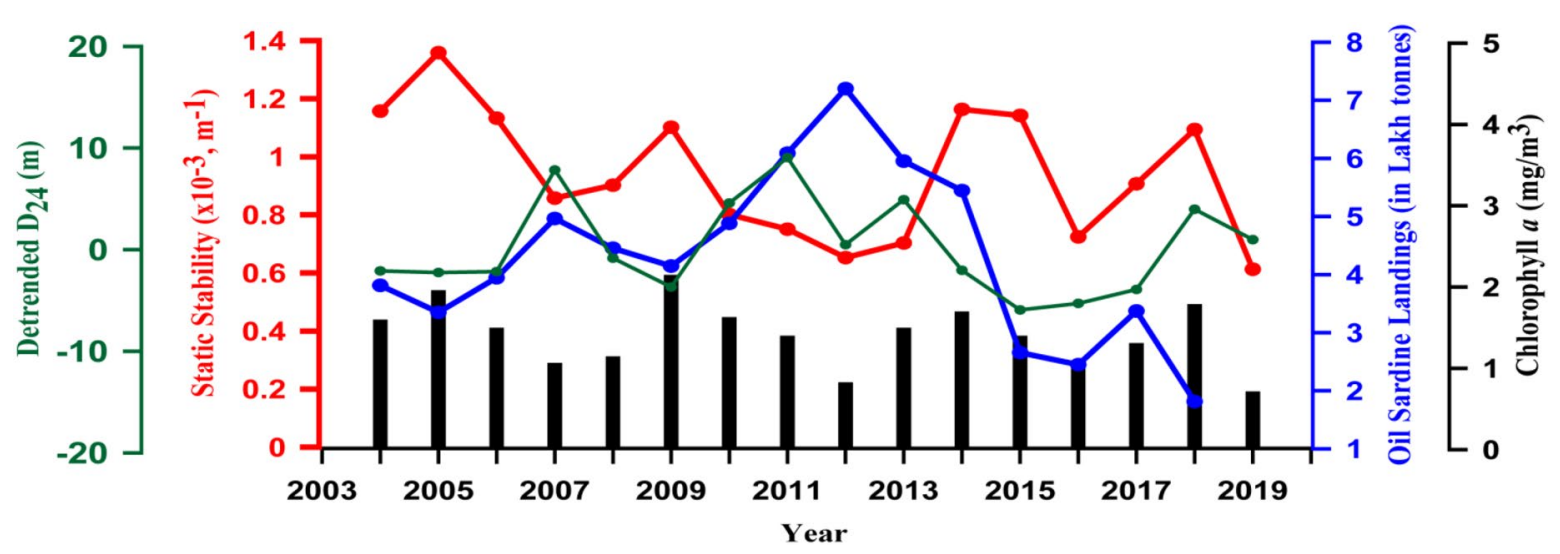

Figure 8. Time series of annual oil sardine landing (lakh tonnes, blue solid line), static stability $\left(\mathrm{m}^{-1}\right.$, red solid line) in the upper $15 \mathrm{~m}$ of the water column, de-trended $\mathrm{D}_{24}$ ( $\mathrm{m}$, green solid line), and chlorophyll $a\left(\mathrm{mg} / \mathrm{m}^{3}\right.$, black solid line) from 2004 to 2019 . The static stability, de-trended $\mathrm{D}_{24}$, and the chlorophyll $a$ were averaged over the boxes $\left(8^{\circ}\right.$ to $\left.12^{\circ} \mathrm{N}\right)$ and for the period from June to September. See Fig. 2 for the location of boxes.

\begin{tabular}{|l|l|l|l|l|l|}
\hline Predictor & Rank & Regression coefficient & Standard error & $\boldsymbol{t}$ & $\boldsymbol{p}>|\boldsymbol{t}|$ \\
\hline Static Stability & 1 & -0.524 & 0.236 & -2.216 & $0.045^{\star}$ \\
\hline De-trended $\mathrm{D}_{24}$ & 2 & 0.496 & 0.224 & 2.001 & $0.050^{\star}$ \\
\hline Chl-a & 3 & -0.325 & 0.262 & -1.238 & 0.238 \\
\hline
\end{tabular}

Table 2. Multiple linear regression analysis with annual oil sardine landings the predictand and parameters such as static stability, de-trended $\mathrm{D}_{24}$, and chlorophyll as predictors for the period 2004-2018. $\mathrm{D}_{24}$ : Depth of 24 degree isotherm, Chl-a: chlorophyll- $a .{ }^{*}$ denotes the values that are statistically significant at $p<0.05$.

stability decreased during the periods from (1) 2005 to 2007, (2) 2009 to 2012, and (3) 2014 to 2016 the Chl-a also showed a decrease. Similarly, during the periods from (1) 2007 to 2009, (2) 2012 to 2014, and (3) 2016 to 2018 when the static stability showed an increase, the Chl-a also increased. This would need an explanation. Recall the presence of low salinity waters in the region from $8^{\circ}$ to $13^{\circ} \mathrm{N}$ in the in situ observation (Fig. $3 \mathrm{~b}$ ), which is due to the freshwater influx in part by river run-off and in part by oceanic precipitation. The river run-off is capable of bringing along with it the land-derived nutrients into the coastal and near-shore waters and enhance the surface Chl-a. This is consistent with the earlier study ${ }^{42}$ in which it was found that riverine nutrients significantly contributed towards the increase of Chl-a, in addition to upwelling in the southern part of the EAS. Though nutrients brought by the freshwater increases the chlorophyll biomass, it is restricted to the thin surface layer, typically less than $20 \mathrm{~m}$. The freshwater, however, will restrict upwelling through stratification and curtail the subsurface nutrient-driven chlorophyll enhancement. Upwelling-driven chlorophyll enhancement takes place within the euphotic zone, which is typically in the upper $50 \mathrm{~m}$ of the water column in the Arabian Sea ${ }^{43}$. The oil sardine being a planktivorous fish, it is the chlorophyll in the euphotic zone that sustains its biomass rather than the surface chlorophyll. This is the reason why there was no connection between the satellite derived Chl-a and the oil sardine landings. Instead, a close connection was noticed between static stability and oil sardine landing, a result which is not reported earlier.

To further substantiate the above result a multiple linear regression analysis was performed to assess the relationship between three predictors such as de-trended $\mathrm{D}_{24}$, static stability, and Chl-a with annual oil sardine landing as predictant. The predictors were ranked on the basis of the magnitude of their standardized regression coefficient presented in Table 2. The static stability was the most important predictor (ranked 1), followed by de-trended $\mathrm{D}_{24}$, both of which were significant at $95 \%$. Chlorophyll was found to be the least important (ranked 3 ) among the predictors and was non-significant. This clearly indicated that the annual oil sardine catch is significantly and negatively correlated with static stability, while the annual oil sardine catch is significantly and positively correlated with de-trended $\mathrm{D}_{24}$. The multiple linear regression analysis confirms the inverse relationship between stratification and oil sardine landings, and reiterates the influence of environmental conditions on the habitat of planktivorous oil sardine ${ }^{41,44}$, which depends largely on the upwelling supported, nutrient-replete habitat ${ }^{9}$.

In order to establish the interdependencies among different parameters of upwelling and oil sardine, we calculated the partial correlation among nine variables viz. $\mathrm{D}_{24}$, static stability, EMT, river discharge, Kerala rainfall, oceanic precipitation, SST, Chl-a and oil sardine landings (Table 3 ). The $\mathrm{D}_{24}$ showed a high correlation with static stability $(-0.76)$, SST $(0.73)$, and oil sardine landings $(0.60)$. This reiterates our result that upwelling is inversely related to the static stability (Fig. 6), but co-varies with oil sardine landings (Fig. 8). 


\begin{tabular}{|l|l|l|l|l|l|l|l|l|l|}
\hline Partial correlation & $\mathbf{D}_{\mathbf{2 4}}$ & $\begin{array}{l}\text { Static } \\
\text { stability }\end{array}$ & EMT & $\begin{array}{l}\text { River } \\
\text { discharge }\end{array}$ & $\begin{array}{l}\text { Kerala } \\
\text { Rainfall }\end{array}$ & $\begin{array}{l}\text { Oceanic } \\
\text { precipitation }\end{array}$ & SST & Chl-a & $\begin{array}{l}\text { Oil Sardine } \\
\text { landings (annual) }\end{array}$ \\
\hline $\mathrm{D}_{24}$ & 1 & & & & & & & & \\
\hline Static stability & $-\mathbf{0 . 7 6}$ & $\mathbf{1}$ & & & & & & & \\
\hline EMT & 0.40 & 0.01 & 1 & & & & & & \\
\hline River discharge & 0.19 & -0.01 & 0.20 & 1 & & & & & \\
\hline Kerala Rainfall & 0.34 & -0.21 & 0.28 & $\mathbf{0 . 8 5}$ & 1 & & & & \\
\hline Oceanic precipitation & $\mathbf{0 . 5 7}$ & $\mathbf{0 . 5 4}$ & 0.36 & $\mathbf{0 . 6 2}$ & $\mathbf{0 . 7 4}$ & 1 & & & \\
\hline SST & $\mathbf{0 . 7 3}$ & $\mathbf{0 . 5 2}$ & $\mathbf{0 . 5 7}$ & -0.11 & 0.14 & 0.42 & 1 & & \\
\hline Chl-a & -0.18 & 0.14 & $\mathbf{0 . 5 7}$ & -0.15 & -0.25 & -0.18 & -0.42 & 1 & \\
\hline Oil Sardine landings (annual) & $\mathbf{0 . 6 0}$ & -0.43 & 0.43 & 0.19 & 0.17 & 0.42 & 0.34 & -0.22 & 1 \\
\hline
\end{tabular}

Table 3. Partial correlation among nine variables viz. $\mathrm{D}_{24}$, static stability, EMT, river discharge, Kerala rainfall, oceanic precipitation, SST, Chl-a and oil sardine landings. All parameters were average during June to September over the boxes from 8 to $12^{\circ} \mathrm{N}$. Valued $>0.5$ is bold faced.

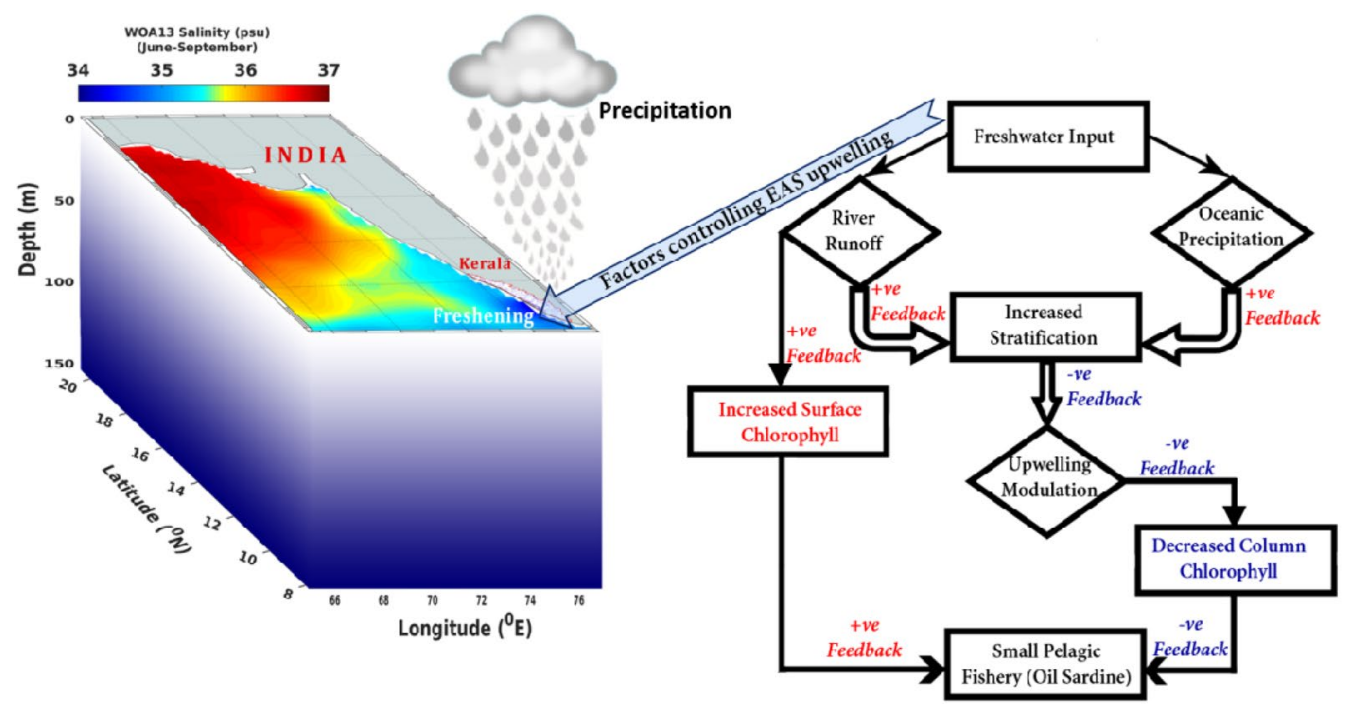

Figure 9. Schematics diagram depicting the mechanistic relationship among freshwater input, stratification, upwelling, chlorophyll, and oil sardine in the EAS. Figure was created using MATLAB and Adobe Photoshop software. See text for details.

In summary, present study adds new information that the interannual variability of upwelling in the EAS is strongly linked to the interannual variation of fresh water influx via Kerala river discharge and oceanic precipitation. Further, a close connection between stratification and oil sardine landings was also deciphered.

The present study revealed that the surface chlorophyll need not always be an indicator of upwelling in the EAS and hence need not be tightly coupled to the small pelagic fishery. This is because the surface chlorophyll can be enhanced by the freshwater influx driven nutrient input, when upwelling is curtailed by stratification. The mechanistic relationship between the fresh water influx, stratification, upwelling, chlorophyll and oil sardine landings are summarised in the schematic diagram (Fig. 9).

The limitation of present study is the lack of data on nutrients, sub-surface chlorophyll, and fish biomass. In the absence of biomass data, though the oil sardine landings data serves as proxy for abundance, it is not the abundance per se. Fish landings data needs to be used with caution. Since oil sardines are fished using various combinations of craft and gear, the landings data are strongly dependent on the fish catch and the efforts put in.

\section{Data and methods}

Upwelling in the EAS being a seasonal phenomenon active during June to September, it is important to capture the signature of upwelling when it is fully developed. As the peak upwelling occurs during July to August, multidisciplinary in situ data was collected from EAS at stations from 8 to $21^{\circ} \mathrm{N}$ (Fig. 2) during August 2017 following the Joint Global Ocean Flux Studies (JGOFS) protocol ${ }^{45}$. The data was collected onboard ORV Sindhu Sadhana from $3^{\text {rd }}$ to $28^{\text {th }}$ August 2017. The Conductivity- Temperature-Depth (CTD) profiles from the surface to nearbottom up to $150 \mathrm{~m}$ were taken at 1-degree latitude interval using Sea-Bird Electronics CTD. 
The temperature and salinity data obtained from the CTD were further used for the computation of static stability following ${ }^{46}$

$$
E=\frac{-1}{\rho}\left[\frac{\partial \rho}{\partial z}\right]
$$

where $\mathrm{E}$ is the static stability $\left(\mathrm{m}^{-1}\right), \rho$ is the density $\left(\mathrm{kg} \mathrm{m}^{-3}\right)$ of the water, and $\mathrm{z}$ is the depth $(\mathrm{m})$.

The 3-day composite profile data of temperature and salinity were obtained from Estimating the Circulation and Climate of the Ocean- Jet Propulsion Laboratory (ECCO-JPL) ${ }^{47,48}$ having a spatial resolution of $0.5 \times 0.5$ degree for the years from 2001 to 2019 (http://apdrc.soest.hawaii.edu/las/v6/constrain?var=5023). Monthly values of temperature and salinity were calculated from 3-day composite profile. This was further used for the computation of depth of $24^{\circ} \mathrm{C}$ isotherm $\left(\mathrm{D}_{24}\right)$ and static stability at station locations from $8^{\circ}$ to $12^{\circ} \mathrm{N}$ for 2001 to 2019 .

The climatological monthly mean data on temperature ${ }^{49}$ and salinity ${ }^{50}$ for August having a spatial resolution of $0.25 \times 0.25$ degrees was obtained from World Ocean Atlas 2013 (WOA13) (http://apdrc.soest.hawaii.edu/las/ v6/dataset?catitem=21428).

The monthly mean SST data for the 2017 was obtained from National Oceanic and Atmospheric Administration (NOAA) Extended Reconstructed SST (ERSST) (http://apdrc.soest.hawaii.edu/las/v6/constrain?var=1262) ${ }^{51}$.

The monthly mean Chl-a pigment concentration having a spatial resolution of $4 \mathrm{~km}$ (zonal) $\times 4 \mathrm{~km}$ (meridional) was obtained from Copernicus-GlobColour using the website https://resources.marine.copernicus.eu/? option=com_csw\&view=order\&record_id=918b8402-78b1-4236-b11e-8202085f0159 which is a merged product of sensors such as SeaWiFS, MODIS, MERIS, VIIRS-SNPP\&JPSS1, OLCI-S\#A\&S\#B ${ }^{52}$. This was used for the computation of seasonal mean during June to September for each year and the climatological seasonal mean for the period 2001 to 2019.

The monthly mean geostrophic current having a spatial resolution of $0.5 \times 0.5$ degree for August 2017 was obtained from Copernicus-Marine Environment Monitoring Service (CMEMS) (https://resources.marine.coper nicus.eu/?option $=$ com_csw\&task=results?option $=$ com_csw\&view=details\&product_id=SEALEVEL_GLO_ PHY_L4_REP_OBSERVATIONS_008_047).

The 6-hourly data of surface winds, zonal (u) and meridional components (v), were taken from the Morden Era Retrospective analysis for Research and Application (MERRA) ${ }^{53}$ having a $0.66 \times 0.5$ degree spatial resolution (http://apdrc.soest.hawaii.edu/las/v6/dataset?catitem=17656). Using $\mathrm{u}$ and $\mathrm{v}$ the zonal and meridional wind stress were calculated using following equations

$$
\begin{aligned}
& \tau_{x}=\rho C_{D} U_{10} u \\
& \tau_{y}=\rho C_{D} U_{10} v
\end{aligned}
$$

where $\rho$ is the density of air taken as $1.22 \mathrm{~kg} \mathrm{~m}^{-3}, \mathrm{C}_{\mathrm{D}}$ is the dimensionless drag coefficient and $\mathrm{U}_{10}$ is the speed of wind at $10 \mathrm{~m}$ above the sea surface. The value of drag coefficient that varies with wind speed as per Large and Pond $^{54}$ were used. Further, the Ekman vertical velocity ${ }^{55}$ and Ekman mass transport ${ }^{56}$ (EMT) were computed following equations

$$
\begin{gathered}
\text { Ekman Vertical velocity }=\frac{-1}{\rho f}\left(\frac{\partial \tau_{y}}{\partial x}-\frac{\partial \tau_{x}}{\partial y}\right) \\
M_{e}=\frac{\tau_{y}}{f}
\end{gathered}
$$

where $\tau_{x}$ and $\tau_{y}$ are the zonal and meridional wind stress components, $\rho$ is the density of seawater taken as $1026 \mathrm{~kg} \mathrm{~m}^{-3}$, and $f$ is the Coriolis parameter and $M_{e}$ is the EMT in $\mathrm{kg} / \mathrm{m} / \mathrm{s}$.

Monthly data on precipitation having a spatial resolution of $0.5 \times 0.5$ degrees for the years 2001 to 2019 were extracted from tropical rainfall measuring mission (TRMM) $)^{57}$ (http://apdrc.soest.hawaii.edu/las/v6/constrain? $\operatorname{var}=13346$ ).

The monthly rainfall data for the state of Kerala for the period 2001 to 2019 was obtained from Indian Institute of Tropical Meteorology (http://www.tropmet.res.in/static_page.php?page_id=53) and Kerala river discharge (2001 to 2018) from Department of water resources, Govt. of India Water Resources Information System (INDIAWRIS) (http://indiawris.gov.in).

The annual national oil sardine landing (tonnes) data available during 2004 to 2018 were obtained from Central Marine Fisheries Research Institute (CMFRI) (www.cmfri.org.in/fish-catch/estimates).

\section{Data availability}

All the data used in the study were downloaded from the open source and the web site details are given under Data and Method. The in situ data on temperature and salinity collected during August 2017 is available with the data repository at CSIR-NIO (https://www.nio.org).

Received: 13 July 2020; Accepted: 17 March 2021

Published online: 31 March 2021 


\section{References}

1. Brown, P. C. \& Hutchings, L. The development and decline of phytoplankton blooms in the southern Benguela upwelling system. 1. Drogue movements, hydrography and bloom development. In Payne, A. I. L., Gulland, J.A. \& Brink, K.H. (eds) The Benguela and Comparable Ecosystems, In: South African Journal of Marine Science 5, 357-391 (1987).

2. Bonino, G. et al. Interannual to decadal variability within and across the major eastern boundary upwelling system s. Sci. Rep. 9, 19949. https://doi.org/10.1038/s41598-019-5651-48 (2019).

3. Jennings, S., Kaiser, M. J. \& Reynolds, J. D. Marine Fisheries Ecology (Blackwell Science, 2001).

4. Smith, S. L. \& Codispoti, L. A. Southwest monsoon of 1979: Chemical and biological response of Somali coastal waters. Science 209, 597-600 (1980).

5. Smith, R. L. \& Bottero, J. S. On upwelling in the Arabian Sea. In A Voyage of Discovery (ed. Angel, M.) (Pergamon, 1977)

6. Banse, K. On upwelling and bottom-trawling off the southwest coast of India. J. Mar. Biol. Ass. India 1, 33-49 (1959).

7. Sharma, G. S. Upwelling off the southwest coast of India. Indian J. Mar. Sci. 17, 16-20 (1978).

8. Longhurst, A. R. \& Wooster, W. S. Abundance of oil sardine (Sardinella longiceps) and upwelling on the southwest coast of India. Can. J. Aquatic Sci. 47, 2407-2419 (1990).

9. Madhupratap, M., Shetye, S. R., Nair, K. N. V. \& Nair, P. S. Oil sardine and Indian mackerel: their fishery problems and coastal oceanography. Curr. Sci. 66, 340-348 (1994).

10. Mohamed, K. S. et al. Marine fisheries of Karnataka state, India. Naga, ICLARM Q. 21, 10-15 (1998).

11. Bakun, A., Roy, C. \& Llucha-Cota, S. Coastal upwelling and other processes regulating ecosystem productivity and fish production in the western Indian Ocean. In Large Marine Ecosystems of the Indian Ocean Assessment, Sustainability and Management (eds Sherman, K. et al.) (Blackwell Science, Cambridge, 1998).

12. Vivekanandan, E., Srinath, M. \& Kuriakose, S. Fishing the marine food web along the Indian coast. Fish. Res. 72, 241-252 (2005).

13. Krishnakumar, P. K. et al. How environmental parameters influenced fluctuations in oilsardine and mackerel fishery during 1926-2005 along south-west coast of India. Mar. Fish. Inf. Serv. T. E. Ser. 198, 1-5 (2008).

14. Manjusha, U., Jayasankar, J., Remya, R., Ambrose, T. V. \& Vivekanandan, E. Influence of coastal upwelling on the fishery of small pelagics off Kerala, south west coast of India. Indian J. Fish. 60, 37-43 (2013).

15. Mohanty, P. K., Khora, S. S., Panda, U. S., Mohapatra, G. N. \& Mishra, P. An Overview of Sardines and Anchovies Fishery Along the Indian Coasts (Berhampur University, 2005).

16. Narvekar, J. et al. Winter-time variability of the eastern Arabian sea: A comparison between 2003 and 2013. Geophys. Res. Lett. https://doi.org/10.1002/2017GL072965 (2017).

17. Shetye, S. West India coastal current and Lakshadweep high/low. Sadhana 23, 637-665 (1998).

18. Naqvi, S. W. A. et al. Increased marine production of $\mathrm{N}_{2} \mathrm{O}$ due to intensifying anoxia on the Indian continental shelf. Nature 408, 346-349 (2000).

19. Prasanna Kumar, S. \& Prasad, T. G. Formation and spreading of Arabian Sea high salinity water mass. J. Geophys. Res. Ocean. 104, 1455-1464 (1999).

20. Prasanna Kumar, S. et al. Intrusion of the Bay of Bengal water into the Arabian Sea during winter monsoon and associated chemical and biological response. Geophys. Res. Lett. 31, L15304. https://doi.org/10.1029/2004GL020247 (2004).

21. Vinayachandran, P. N., Shankar, D., Kurian, J., Durand, F. \& Shenoi, S. S. C. Arabian Sea mini warm pool and the monsoon onset vortex. Curr. Sci. 93, 203-214 (2007).

22. Smitha, B. R., Sanjeevan, V. N., Vimal Kumar, K. G. \& Revichandran, C. On the upwelling off the southern tip and along the west coast of India. J. Coastal Res. 24, 95-102 (2008).

23. Shah, P., Sajeev, R. \& Gopika, N. Study of upwelling along the west coast of India-a climatological approach. J. Costal Res. 31, 1151-1158 (2015).

24. Gupta, G. V. M. et al. Evolution to decay of upwelling and associated biogeochemistry over the southern Arabian Sea shelf. J. Geophys. Res. Biogeosci. 121, 159-175. https://doi.org/10.1002/2015JG003163 (2016).

25. Antony, M. K., Swamy, G. N. \& Somayajulu, Y. K. Offshore limit of coastal ocean variability identified from hydrography and altimeter data in the eastern Arabian Sea. Cont. Shelf Res. 22, 2525-2536 (2002).

26. Menon, N. N. et al. Satellite chlorophyll concentration as an aid to understanding the dynamics of Indian oil sardine in the southeastern Arabian Sea. Mar. Ecol. Prog. Ser. 617, 137-147 (2018).

27. Muraleedharan, P. M. \& Prasanna Kumar, S. Arabian Sea upwelling-A comparison between coastal and open ocean regions. Curr. Sci. 71, 842-846 (1996).

28. Shetye, S. R., Shenoi, S. S. C., Antony, M. K. \& Kumar, V. K. Monthly-mean wind stress along the coast of the North Indian Ocean. Proc. Indian Acad. Sci. Earth Planet. Sci. 94, 129-137 (1985).

29. McCreary, J. P., Kundu, P. K. \& Molinari, R. L A numerical investigation of dynamics, thermodynamics and mixed layer processes in the Indian Ocean. Prog. Oceanogr. 31, 181-244 (1993).

30. Shankar, D. \& Shetye, S. R. On the dynamics of the Lakshadeep high and Low in the southeastern Arabian Sea. J. Geophys. Res. Ocean. 102, 12551-12562 (1997).

31. Rao, R. R. et al. Interannual variability of Kelvin wave propagation in the wave guides of the equatorial Indian Ocean, the coastal Bay of Bengal and the southeastern Arabian Sea during 1993-2006. Deep-Sea Res. Part I 57, 1-13 (2009).

32. Hareesh Kumar, P. V. \& Anand, P. Coastal upwelling off the southwest coast of India: observations and simulations. Int. J. Digi. Earth. 9, 1256-1274. https://doi.org/10.1080/17538947.2016.1216614 (2016).

33. Jayaram, C., Neethu, C., Ajith, J. K. \& Balchand, A. N. Interannual variability of upwelling indices in the southeastern Arabian Sea: a satellite based study. Ocean Sci. J. 45, 27-40 (2010).

34. Jayaram, C. \& Dinesh Kumar, P. K. Spatio-temporal variability of upwelling along the southwest coast of India based on satellite observations. Cont. Shelf Res. 156, 33-42 (2018).

35. Krishnakumar, P. K. \& Bhat, G. S. Seasonal and interannual variations of oceanographic conditions off Mangalore coast (Karnataka, India) during 1995-2004 and their influences on pelagic fishery. Fish. Oceanogr. 17, 45-60 (2008).

36. Pillai, V. N., Rajan, P. K. V. \& Nandakumar, A. Oceanographic investigations along the southwest coast of India (1976-98). A report prepared for Pelagic fishery investigations on the southwest coast, Phase II project, FAO/UNDP, Document 5 (1980).

37. CWRDM. Water atlas. CWRDM, Kerala, Kozhikode, India (1995).

38. Nicholson, S. E. \& Entekhabi, D. Rainfall variability in equatorial and southern Africa Relationships withsea surface temperatures along the southwestern coast of Africa. J. Clim. Appl. Meteorol. 26, 561-578 (1987).

39. Royer, T. C. On the effect of precipitation and runoff on coastal circulation in the Gulf of Alaska. J. Phys. Oceanogr. 9, 555-563 (1979).

40. Gopinathan, C. K. Early stages of upwelling and decline in oil-sardine fishery of Kerala. J. Mar. biol. Ass. India 16(3), 700-7007 (1974).

41. Devaraj, M. et al. Status, Prospects and Management of Small Pelagic Fisheries in India Vol. 31 (RAP Publications, FAO, 1997).

42. Shafeeque, M. et al. Effect of precipitation on chlorophyll- $a$ in an upwelling dominated region along the west coast of India. $J$. Coastal Res. 86, 218-224 (2019).

43. Qasim, S. A. Biological productivity of the Indian Ocean. Indian J. Mar. Sci. 6, 122-137 (1977). 
44. Schwartzlose, R. A. et al. Worldwide large-scale fluctuations of sardine and anchovy populations. S. Afr. J. Mar. Sci. 21(289-347), 1999. https://doi.org/10.2989/025776199784125962 (1999).

45. UNESCO. Protocols for the Joint Global Ocean Flux Study (JGOFS), core measurements, IOC Manual Guides Ser. 29, Paris (1994).

46. Pond, S. \& Pickard, G. L. Introductory Dynamical Oceanography (University of British Columbia, 1983).

47. Forget, G. et al. ECCO version 4: An integrated framework for non-linear inverse modelling and global ocean state estimation. Geoscientific Model Development. 8, 3071-3104. https://doi.org/10.5194/gmd-8-3071-2015 (2015).

48. Fukumori, I., Wang, O., Fently, I., Forge, G., Heimbach, P. \& Ponte, R.M. ECCO Version4 Release 3. http://hdl.handle.net/1721.1/ 110380. doi:1721.1/110380 (2017).

49. Locarnini, R. A., Mishonov, A. V., Antonov, J.I., Boyer, T. P., Garcia, H. E., Baranova, O. K., Zweng, M. M., Paver, C.R., Reagan, J. R., Johnson, D. R., Hamilton, M. \& Seidov, D. World Ocean Atlas 2013, Volume 1: Temperature. S. Levitus, Ed., A. Mishonov Technical Ed.; NOAA Atlas NESDIS 73 (2013).

50. Zweng, M.M., Reagan, J. R., Antonov, J. I., Locarnini, R. A., Mishonov, A. V., Boyer, T.P., Garcia, H. E., Baranova, O. K., Johnson, D. R., Seidov, D. \& Biddle, M. M. World Ocean Atlas 2013, Volume 2: Salinity. S. Levitus, Ed., A. Mishonov Technical Ed.; NOAA Atlas NESDIS 74 (2013).

51. Huang, B. et al. Extended reconstructed sea surface temperature version4 (ERSST.v4) Part I: upgrades and intercomparisons. J. Clim. 28, 911-930. https://doi.org/10.1175/JCLI-D-14-00006.1 (2015).

52. Garnesson, P., Mangin, A., Fanton d'Andon, O., Demaria, J. \& Bretagnon, M. The CMEMS GlobColour chlorophyll aproduct based on satellite observation: multi-sensor merging and flagging strategies. Ocean Sci. 15, 819-830. https://doi.org/10.5194/os-15-8192019 (2019)

53. Gelaro, R. et al. The modern-era retrospective analysis for research and applications, version 2 (MERRA-2). J. Clim. 30, 5419-5454. https://doi.org/10.1175/JCLI-D-16-0758.1 (2017).

54. Large, W. G. \& Pond, S. Open ocean momentum flux measurements in moderate to strong winds. J. Phys. Oceanogr. 11, 324-336 (1981).

55. Gill, A. E. Atmosphere-Ocean Dynamics (Academic Press Inc., 1982).

56. Koracin, D., Dorman, C. E. \& Dever, E. P. Coastal perturbations of marine-layer winds, wind stress and wind stress curl along California and Baja California in June 1999. J. Phys. Oceanogr. 34, 1152-1173 (2004).

57. Huffman, G.J., Adler, R. F. \& Bolvin, D. T., Nelkin, E. J. The TRMM Multi-satellite Precipitation Analysis (TMPA). Chapter 1. In: Satellite Rainfall Applications for Surface Hydrology. https://doi.org/10.1007/978-90-481-2915-7 (2010).

\section{Acknowledgements}

The authors thank Director CSIR-National Institute of Oceanography (CSIR-NIO), Goa and Council of Scientific and Industrial Research (CSIR), New Delhi for all the support and encouragement for this research which forms a part of the CSIR funded project MLP1802. SPK was funded by CSIR-Emeritus Scientist project ES84091(RIOCC-AMEF). The authors also thank three anonymous reviewers for their constructive comments which helped to improve the manuscript. The authors wish to acknowledge the use of the Ferret software for analysis and graphics (http://ferret.pmel.noaa.gov/Ferret/). The graphics were also created using MATALAB R2017a (https:// in.mathworks.com/) and QGIS (http://qgis.org) softwares, while Adobe Photoshop (https://www.adobe.com/ in/products/photoshop/free-trial-download.html\#) software was used for the generation of schematic diagram. This is NIO contribution number 6707.

\section{Author contributions}

J.N. conceived the idea and designed shipboard experiment. J.N. and D.G. participated in the data collection. J.N. and R.R.C contributed towards data analysis. J.N., R.R.C. and P.K.D. prepared Figs. 1-9. J.N. and S.P.K interpreted the results and wrote the paper. All authors reviewed the manuscript.

\section{Competing interests}

The authors declare no competing interests.

\section{Additional information}

Correspondence and requests for materials should be addressed to J.N.

Reprints and permissions information is available at www.nature.com/reprints.

Publisher's note Springer Nature remains neutral with regard to jurisdictional claims in published maps and institutional affiliations.

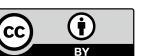

Open Access This article is licensed under a Creative Commons Attribution 4.0 International License, which permits use, sharing, adaptation, distribution and reproduction in any medium or format, as long as you give appropriate credit to the original author(s) and the source, provide a link to the Creative Commons licence, and indicate if changes were made. The images or other third party material in this article are included in the article's Creative Commons licence, unless indicated otherwise in a credit line to the material. If material is not included in the article's Creative Commons licence and your intended use is not permitted by statutory regulation or exceeds the permitted use, you will need to obtain permission directly from the copyright holder. To view a copy of this licence, visit http://creativecommons.org/licenses/by/4.0/.

(C) The Author(s) 2021 